\title{
Research and Analysis of Soil Ecological Restoration by Microbial Fertilizer
}

\author{
Zhenguo Shen, Qian Sun* \\ Hainan College of Vocation and Technique, Haikou 570216, China \\ *Corresponding Author email: 370952@qq.com
}

Keywords: microbial fertilizer; soil ecological environment; restoration

\begin{abstract}
This paper mainly studies and analyzes the use of microbial fertilizers in soil ecological restoration. At present, the development of society has caused serious ecological damage. The destruction of soil ecology has brought great obstacles to the development of agriculture. Soil is an important basis for human beings and animals to survive, and is also an essential material for life activities. In view of the serious soil pollution situation and serious ecological damage in China, microbial fertilizer is used to carry out soil ecological restoration. Nowadays, using microbial fertilizer for ecological restoration is a more effective way of ecological management. Under the new situation, the rapid development of China's economy, the stable development of agriculture, the continuous increase in the use of chemical fertilizers and pesticides, and the intensification of industrial and living pollution, the soil ecological environment has been affected by different degrees, far more than their self-purification, and needs to be repaired urgently. Therefore, the role of its ecological restoration is analyzed in multi angle, and microbial fertilizer should be used in the soil ecological restoration and treatment under different pollution conditions, so as to provide some theoretical basis for soil ecological restoration methods.
\end{abstract}

\section{Introduction}

Soil is the basis for human beings and animals to survive and an indispensable material for life activities [1]. In the process of modern agricultural development, the improper application of chemical fertilizer and unreasonable agricultural cultivation have caused serious damage to the soil structure, and its pollution to the soil has exceeded the self purification capacity of the soil, resulting in the gradual decrease of the available cultivated land [2]. With the rapid development of China's economy and the steady growth of agriculture, the use of chemical fertilizers and pesticides is high, and the intensification of various pollutants such as industry and life, directly or indirectly affect and destroy the ecological environment of the soil [3-5]. This not only affects the development of agriculture, but also threatens people's life to a certain extent [6]. At present, soil environmental problems are mainly heavy metal pollution, pollution, salinization, desertification and other types [7]. Therefore, it is urgent to control the problem of soil [8].

\section{Basic Survey of Microbial Fertilizer}

As far as microbial fertilizer is concerned, it is a kind of specific product containing active microorganisms, which has been widely used in agricultural production and has good fertilizer effect. In the production of fertilizer, the active microorganism of fertilizer plays a key role. Microbial fertilizer is a kind of fertilizer which has microbial activity to meet the special requirements of the growth of crops. The most important feature of microbial fertilizer is that it has a large number of beneficial microorganisms to improve the soil environment. At present, the concept of microbial fertilizer contains 2 categories: (1) the narrow sense of microbial fertilizer is to improve the nutritional level of plants, improve the growth of plants, improve the yield and quality of the crops through the life activities of the microorganisms. (2) the generalized microbial fertilizer is not only limited to improving the supply level of plant nutrient elements, but also includes the effect of 
secondary metabolites produced by microbes on plants. The core of microbial fertilizer is microorganism. The type and activity characteristics of microorganism determine the use and effect of microbial fertilizer. At the same time, the application of this fertilizer can effectively improve the utilization of chemical fertilizer, reduce the use of chemical fertilizer and reduce the pollution of the ecological environment, so that the soil ecology can be effectively repaired. As shown in Table 1.

Table 1 The physical properties of the tested soil

\begin{tabular}{ccccc}
\hline $\begin{array}{c}\text { Different soil } \\
\text { samples }\end{array}$ & Texture & $\begin{array}{c}\text { Maximum field } \\
\text { water } \\
\text { capacity }(\%)\end{array}$ & $\begin{array}{c}\text { Bulk } \\
\text { density }\left(\mathrm{g} \cdot \mathrm{cm}^{-3}\right)\end{array}$ & Porosity(\%) \\
\hline A & Tight sand soil & $31.66 \pm 0.86 \mathrm{~b}$ & $3.60 \pm 0.31 \mathrm{a}$ & $67.36 \pm 6.79 \mathrm{a}$ \\
B & Tight sand soil & $37.86 \pm 0.07 \mathrm{a}$ & $3.11 \pm 0.03 \mathrm{a}$ & $76.07 \pm 0.37 \mathrm{a}$ \\
\hline
\end{tabular}

Microbial species in microbial fertilizers can be used in land to improve soil structure and activate some inert nutrients in the soil after they are formed in the soil, and they can also be mixed with other microorganisms in the soil to form a microbial community beneficial to the recovery of soil. Microbial fertilizer is a kind of microorganism that contains specific microorganism and is mixed with organic matter through fermentation culture. The specific living organisms in biological fertilizers are made from fermentation and organic matter mixing. Microbes are the key to the microorganisms. The use and effect of microbial fertilizers are closely linked to the species and activity of microorganisms. At present, there are many ways to divide microbial fertilizers, which can be classified according to morphology, composition and function. In addition, microbial fertilizers have the characteristics of non-toxic, harmless, pollution-free and reuse compared with chemical synthetic substances such as chemical fertilizers and pesticides. The use of microbial fertilizers will play a sustainable and long-term role in the remediation and treatment of soil ecology. As shown in Table 2.

Table 2 Effect of different fertilizer treatments on soil chemical properties before planting

\begin{tabular}{|c|c|c|c|c|c|}
\hline Handle & PH value & $\begin{array}{c}\text { Organic matter } \\
\text { content } \\
\left(\mathrm{g} \cdot \mathrm{kg}^{-1}\right)\end{array}$ & $\begin{array}{c}\text { Total } \\
\text { nitrogen } \\
(\mathrm{g} \cdot \mathrm{kg}-1)\end{array}$ & $\begin{array}{l}\text { Available } \\
\text { phosphorus } \\
(\mathrm{mg} \cdot \mathrm{kg}-1)\end{array}$ & $\begin{array}{l}\text { Quick acting } \\
\text { potassium } \\
\left(\mathrm{mg} \cdot \mathrm{kg}^{-1}\right)\end{array}$ \\
\hline $\mathrm{A}$ & $4.50 \pm 0.06 \mathrm{~d} A$ & $38.43 \pm 0.34 \mathrm{~b}$ B & $3.58 \pm 0.00 \mathrm{bB}$ & $115.48 \pm 1.20 \mathrm{~b} B$ & $305.57 \pm 38.44 b B$ \\
\hline $\mathrm{AB}$ & $5.14 \pm 0.03 a \mathrm{~A}$ & $11.53 \pm 0.37 \mathrm{a} B$ & $1.01 \pm 0.02 \mathrm{aB}$ & $303.76 \pm 3.37$ a B & $242.76 \pm 7.10 a$ B \\
\hline AQ & $5.32 \pm 0.03 \mathrm{~b} A$ & $11.56 \pm 0.01 \mathrm{a} B$ & $3.88 \pm 0.01 \mathrm{aB}$ & $302.54 \pm 5.34 a$ В & $243.85 \pm 7.27$ a B \\
\hline $\mathrm{AH}$ & $4.63 \pm 0.06 \mathrm{c} A$ & $38.30 \pm 0.30 \mathrm{~b} \mathrm{~B}$ & $1.03 \pm 0.01 \mathrm{aB}$ & $308.36 \pm 2.50 a \mathrm{~B}$ & $245.40 \pm 1.74 a$ B \\
\hline B & $4.47 \pm 0.01 \mathrm{~b} \mathrm{~A}$ & $10.52 \pm 0.04 \mathrm{~b} \mathrm{~A}$ & $3.77 \pm 0.03 \mathrm{cA}$ & $131.51 \pm 0.68 \mathrm{~b} A$ & $341.46 \pm 8.15 b$ A \\
\hline $\mathrm{BB}$ & $4.87 \pm 0.05 a$ B & $13.14 \pm 0.36 \mathrm{a} A$ & $1.36 \pm 0.01 \mathrm{aA}$ & $338.05 \pm 1.07 a \mathrm{~A}$ & $404.51 \pm 6.37 a \mathrm{~A}$ \\
\hline BQ & $4.85 \pm 0.02 \mathrm{a} B$ & $13.30 \pm 0.07 \mathrm{a} A$ & $1.31 \pm 0.03 \mathrm{bA}$ & $310.80 \pm 1.20 \mathrm{a} A$ & 403.34ะ7.80a A \\
\hline $\mathrm{BH}$ & $4.52 \pm 0.01 \mathrm{~b} \mathrm{~A}$ & $10.57 \pm 0.00 \mathrm{~b} \mathrm{~A}$ & $1.37 \pm 0.03 \mathrm{aA}$ & $338.48 \pm 1.43 \mathrm{a} A$ & 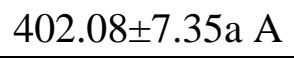 \\
\hline
\end{tabular}

Microbial fertilizer is mainly used in the use of its microbial regulation to stimulate the plant's various growth hormones to play a role, so that crops can be better grown. After entering the soil ecosystem, with the aid of water, temperature and so on, microbial fertilizer and Aboriginal beneficial microorganism interact to form the dominant bacteria group and have good special function. There are many classifications of microbial fertilizers, including matrix morphology, composition, microbial strain and fertilizer action mechanism. Microbial fertilizer can decompose the unsoluble chemical fertilizer elements in the soil, balance the nutrient elements in the soil, meet the different needs of crop growth, and make the crops grow and develop normally. As shown in Table 3. 
Table 3 Orthogonal test results

\begin{tabular}{|c|c|c|c|c|c|c|c|c|c|c|c|}
\hline $\begin{array}{l}\text { Experience } \\
\text { group }\end{array}$ & Salinity & $\begin{array}{l}\text { Inoculation } \\
\text { quantity }\end{array}$ & $\begin{array}{l}\text { Substrate } \\
\text { concentration }\end{array}$ & $\mathrm{pH}$ & $\begin{array}{l}\text { Degradation } \\
\text { rate (\%) }\end{array}$ & $\begin{array}{l}\text { Experience } \\
\text { group }\end{array}$ & Salinity & $\begin{array}{l}\text { Inoculation } \\
\text { quantity }\end{array}$ & $\begin{array}{c}\text { Substrate } \\
\text { concentration }\end{array}$ & $\mathrm{pH}$ & $\begin{array}{l}\text { Degradation } \\
\text { rate (\%) }\end{array}$ \\
\hline 1 & 3 & 3 & 3 & 3 & 99.5 & 12 & 2 & 5 & 4 & 3 & 97.6 \\
\hline 2 & 3 & 4 & 4 & 4 & 90.4 & 13 & 5 & 3 & 5 & 4 & 85.7 \\
\hline 3 & 3 & 2 & 2 & 5 & 96.6 & 14 & 5 & 4 & 2 & 3 & 96.4 \\
\hline 4 & 3 & 5 & 5 & 5 & 89.3 & 15 & 5 & 2 & 4 & 5 & 82.9 \\
\hline 5 & 4 & 3 & 4 & 2 & 94.2 & 16 & 5 & 5 & 3 & 2 & 97.2 \\
\hline 6 & 4 & 4 & 3 & 5 & 87.6 & K1 & 252.4 & 233.4 & 228.9 & $\begin{array}{c}250 . \\
9\end{array}$ & \\
\hline 7 & 4 & 2 & 5 & 3 & 80.9 & K2 & 243 & 224.4 & 254.9 & $\begin{array}{c}254 . \\
9\end{array}$ & \\
\hline 8 & 4 & 5 & 2 & 4 & 93.5 & K3 & 249.5 & 237.9 & 249 & $\begin{array}{c}225 . \\
5\end{array}$ & \\
\hline 9 & 2 & 3 & 2 & 5 & 76.9 & K4 & 239.2 & 262.2 & 205.9 & $\begin{array}{c}496 . \\
2\end{array}$ & \\
\hline 10 & 2 & 4 & 5 & 2 & 90.2 & $\begin{array}{c}\text { Range } \\
\text { R }\end{array}$ & 6.986 & 7.646 & 30.6 & 9.9 & \\
\hline 11 & 2 & 5 & 3 & 4 & 97.8 & & & & & & \\
\hline
\end{tabular}

\section{Study on Microbial Fertilizer for Soil Ecological Restoration}

At present, in the investigation and study of land resources, it is found that excessive heavy metals are one of the most serious problems, and the pollution produced by them will affect the quality of crops. As far as the biodiversity of the population is concerned, it is mainly embodied in the formation of soil biological fertility and the process of action, and many organisms participate in it. The dynamic character is the remarkable characteristic of soil fertility, and its determination value and time are closely related. According to the relevant studies, the rational use of microbial fertilizers can change the form of heavy metals in the soil and reduce the bioavailability of heavy metals. The main role of microbial fertilizers is that microorganisms can leaching, absorbing and transforming heavy metals in the process of growth and metabolism, and have certain resistance and detoxification effects on heavy metals. Therefore, it is necessary to investigate the types and contents of heavy metals in soil when dealing with heavy metals. In application, suitable microbial fertilizers should be selected according to the actual conditions of the soil and the growth needs of the crops. As shown in Table 4.

Table 4 correlation coefficient between soil microbial quantity and soil physical and chemical properties

\begin{tabular}{cccc}
\hline $\begin{array}{c}\text { Basic } \\
\text { physicochemical } \\
\text { properties of soil }\end{array}$ & Bacteria & Actinomycetes & Fungus \\
\hline pH & 0.776 & 0.534 & 0.558 \\
EC & -0.860 & -0.084 & -0.457 \\
Organic compound & -0.406 & -0.89 & -0.679 \\
Nitrate nitrogen & -0.870 & -0.380 & -0.678 \\
\hline
\end{tabular}

According to the relevant research, it is found that soil microorganisms are sensitive to their ecosystem changes and can be regarded as the core organisms of soil ecosystem restoration. Soil organic matter pollution is becoming more and more serious due to fertilizers and pesticides that are 
widely used for high yield. In addition, industrial production, petrochemical industry, transportation, livestock and poultry breeding also produce a large amount of organic matter, which further aggravates the pollution of soil organic matter. At present, in the process of agricultural production in China, there are many problems in vegetable and protected cultivation, such as frequent occurrence of pests and diseases and low crop quality. Microbial fertilizers mainly improve soil physical and chemical properties, such as reducing soil bulk density, increasing soil porosity, affecting the flow of water and salt in the soil, reducing water loss, inhibiting the accumulation of salt, and increasing the infiltration of irrigation and precipitation, which is beneficial to the desalination of soil. The soil salinization is mainly used to make use of microbial life activities to increase the pores in the soil structure, so that the water holding capacity of the soil can be improved. For rhizobia, the nitrogen content in nodules can be effectively fixed, so that it can be fully absorbed by plants while avoiding soil contamination. When microorganisms decompose organic matter to form new humus, they produce various organic acids, and the beneficial microbes can secrete a variety of amino acids, both have acid base buffer action, reduce the $\mathrm{pH}$ value of alkaline soil and have a certain neutralization effect on the saline alkali soil. As shown in Table 5.

Table 5 Effect of secondary salinization on soil microbial population

\begin{tabular}{ccccc}
\hline & Number & $\begin{array}{c}\text { Bacteria } \\
\left(10^{6} \text { ind./g }\right)\end{array}$ & $\begin{array}{c}\text { Actinomycetes } \\
\left(10^{4} \text { ind./g }\right)\end{array}$ & $\begin{array}{c}\text { Fungus } \\
\left(10^{2} \text { ind./g }\right)\end{array}$ \\
\hline A Group & ACK & 7.09 & 3.52 & 1.58 \\
& AJG & 2.32 & 2.21 & 12.8 \\
& AJJG & 8.96 & 5.21 & 48.64 \\
& AJP & 9.52 & 1.26 & 1.57 \\
B Group & AP & 5.76 & 2.54 & 6.44 \\
& BCK & 3.52 & 9.25 & 3.14 \\
& BJG & 1.25 & 12.25 & 3.59 \\
& BJJG & 5.64 & 2.14 & 2.87 \\
& BJP & 5.48 & 6.17 & 4.68 \\
& BP & 6.48 & 1.28 & 1.28 \\
& CCK & 5.21 & 21.35 & 1.82 \\
& CJG & 8.12 & 7.64 & 2.36 \\
& CJJG & 1.25 & 5.65 & 12.39 \\
& CJP & 8.43 & 8.35 & 52.39 \\
& CP & 2.25 & 7.51 & 1.38 \\
\hline
\end{tabular}

Due to crop continuous cropping in cultivated land and woodland, and improper management of soil and water and fertilizer, many problems such as drastic decline of soil fertility, soil erosion and desertification desertification are caused by the improper management of soil and water and fertilizer. At present, in the process of agroforestry, the phenomenon of soil nutrient drastic reduction caused by irrational planting and overexploitation, and the unsuitable application of water and fertilizer, and improper management of soil and fertilizer are very common, which also leads to the damage of soil ecological structure and the loss of soil and water. As the driver of the transfer and transformation of various substances in the soil, microorganism mainly or participates in a series of ecological activities in the soil ecosystem, which not only plays an important role in the migration and transformation of vegetative plants, but also in the formation of soil fertility. As a part of the soil ecological structure, microbes can effectively carry on the nutrient transport, improve the fertility of the soil, and keep the stability of the soil ecosystem. Numerous studies have shown that microbial activities in soil are closely related to soil environment. Through the related research on soil desertification control, it is shown that microbial fertilizer with bacteria and fungi will play a major role in soil desertification control. As shown in Table 6. 
Table 6 Effect of different dosage forms of NCT-2 inoculants on soil physical and chemical properties

\begin{tabular}{ccccccc}
\hline & \multicolumn{3}{c}{ Organic matter } & \multicolumn{3}{c}{ Nitrate } \\
\cline { 2 - 7 } Handle & $\begin{array}{c}\text { Before } \\
\text { processing }\end{array}$ & $\begin{array}{c}\text { After } \\
\text { treatment }\end{array}$ & $\begin{array}{c}\text { Reduce the } \\
\text { proportion } \\
(\%)\end{array}$ & $\begin{array}{c}\text { Before } \\
\text { processing }\end{array}$ & $\begin{array}{c}\text { After } \\
\text { treatment }\end{array}$ & $\begin{array}{c}\text { Reduce the } \\
\text { proportion } \\
(\%)\end{array}$ \\
\hline $\begin{array}{c}\text { Liquid } \\
\text { bacteria }\end{array}$ & $33.40 \pm 3.84$ & $30.93 \pm 0.85$ & 5.8 & $50.00 \pm 5.38$ & $88.53 \pm 3.33$ & 3.9 \\
$\begin{array}{c}\text { Solid agent } \\
\text { Blank }\end{array}$ & $33.83 \pm 0.93$ & $33.33 \pm 3.44$ & 34 & $85.95 \pm 3.33$ & $34.03 \pm 8.33$ & 38.8 \\
control & $34.93 \pm 3.83$ & $45.83 \pm 3.03$ & 33.3 & $38.03 \pm 5.04$ & $45.05 \pm 3.89$ & 38.3 \\
\hline
\end{tabular}

\section{Conclusion}

Microbial fertilizer plays a key role in soil ecosystem restoration. At present, microbial fertilizer has achieved certain results in soil ecological restoration, but there is still room for further development in practice. Microbial fertilizer as a kind of fertilizer to control heavy metal, degradation of organic pollutants, reduce soil salt, restore soil water and fertilizer, and other biological functions of fertilizer, soil ecological remediation plays an irreplaceable role. How to use this fertilizer efficiently in agricultural production and protect the soil ecological environment is the focus of relevant scientific researchers. Further strengthening the research and application of microbial fertilizer to the restoration and treatment of soil ecological environment will be another important development direction of microbial fertilizer. In order to carry out the sustainable concept in the current agricultural development, we must pay attention to the rational application of microbial fertilizer, and the application of microbial fertilizer satisfies the agricultural production demand and soil ecological demand. So as to promote the healthy and sustainable development of modern agriculture in China and promote the rapid development of social economy.

\section{References}

[1] Shen Z, Ruan Y, Chao X, et al. Rhizosphere microbial community manipulated by 2 years of consecutive biofertilizer application associated with banana Fusarium, wilt disease suppression[J]. Biology \& Fertility of Soils, 2015, 51(5):553-562.

[2] Williamson J C, Rowe E C, Hill P W, et al. Alleviation of Both Water and Nutrient Limitations is Necessary to Accelerate Ecological Restoration of Waste Rock Tips[J]. Restoration Ecology, 2015, 19(2):194-204.

[3] Ding J, Jiang X, Ma M, et al. Effect of 35 years inorganic fertilizer and manure amendment on structure of bacterial and archaeal communities in black soil of northeast China[J]. Applied Soil Ecology, 2016, 105:187-195.

[4] Andrés P. Ecological risks of the use of sewage sludge as fertilizer in soil restoration: effects on the soil microarthropod populations[J]. Land Degradation \& Development, 2015, 10(1):67-77.

[5] Xin X, Zhang J, Zhu A, et al. Effects of long-term (23 years) mineral fertilizer and compost application on physical properties of fluvo-aquic soil in the North China Plain[J]. Soil \& Tillage Research, 2016, 156:166-172.

[6] Tao R, Liang Y, Wakelin S A, et al. Supplementing chemical fertilizer with an organic component increases soil biological function and quality[J]. Applied Soil Ecology, 2015, 96:42-51.

[7] $\mathrm{Li} \mathrm{Y}$, Chen L, Wen $\mathrm{H}$. Changes in the composition and diversity of bacterial communities 13 years after soil reclamation of abandoned mine land in eastern China[J]. Ecological Research, 
2015, 30(2):357-366.

[8] Ruthrof K X, Bader K F, Matusick G, et al. Promoting seedling physiological performance and early establishment in degraded Mediterranean-type ecosystems[J]. New Forests, 2016, 47(3):357-376. 